Cakrawala Dini: Jurnal Pendidikan Anak Usia Dini | p-ISSN 2087-1317 | e-ISSN 2621-8321

Vol. 12. No.2 November 2021 | Hal I25-135

\title{
THE EFFECT OF WEAVING ACTIVITIES WITH BANANA LEAVES ON FINE MOTOR ABILITY EARLY OF CHILDHOOD
}

\author{
Irmawati $^{1}$, Ichsan $^{2}$ \\ ${ }^{1,2}$ Universitas Islam Negeri Sunan Kalijaga Yogyakarta
}

\begin{abstract}
This research aims to determine the effect of weaving activities on fine motor skills in TK Pertiwi 26-13 Bogares Kidul. This research uses a quantitative approach method by carrying out Field Research. This research presents data in the form of numbers using statistical data analysis which has the aim of testing hypotheses and data analysis using regression analysis. The results of the research show that the regression analysis of $Y=5.592+0.579 X$, the equation shows a lot of at least a child's fine motor capacity. Banana leaf weaving affects the fine motor skills of Pertiwi Kindergarten 26-13 Bogares Kidul. The conclusions drawn are: banana leaf weaving give positive affects on fine motor skills development of Pertiwi Kindergarten 26-13 Bogares Kidul children. The contribution of the effectiveness of banana leaf weaving to fine motor skills is seventy-four percent. Based on the reaction analysis and analysis that has been carried out in this research, it can be concluded that the banana leaf weaving variable has a positive and increasing effect on fine motor skills.
\end{abstract}

Keywords: Weaving Banana Leaves; Fine Motor; Early Childhood

\begin{abstract}
Abstrak: Riset ini memiliki tujuan agar mengetahui pengaruh aktivitas menganyam terhadap keterampilan motorik halus di TK Pertiwi 26-13 Bogares kidul. Riset ini mamakai metode pendekatan kuantitatif dengan melaksanakan Field Research. Pada riset ini menyajikan data dengan bentuk angka memakai analisis data statistik yang memiliki tujuan agar menguji hipotesis serta analisis data memakai analisis regresi. Hasil Riset memperlihatkan analisis regresi $\mathrm{Y}=5.592+0,579 \mathrm{X}$ persamaan itu memperlihatkan banyak sedikitnya kapasitas motorik halus anak. Mengayam daun pisang memiliki pengaruh terhadap kemampuan motorik halus anak TK Pertiwi 26-13 Bogares Kidul. Kesimpulan yang diambil adalah: mengayam daun pisang berpengaruh terhadap kemampuan motorik halus anak TK Pertiwi 26-13 Bogares Kidul dengan hasil uji t memperoleh nilai thitung lebih dari ttabel. Banyaknya kontribusi keefektifan mengayam daun pisang terhadap kemampuan motorik halus memperoleh tujuh puluh empat persen. Berlandaskan reaksi analisis serta analisis yang sudah dilaksanakan pada riset ini, untuk itu bisa ditarik simpulan variabel Mengayam daun pisang meliki pengaruh baik serta meningkat pada Motorik Halus.
\end{abstract}

Kata Kunci: Mengayam Daun Pisang, Motorik Halus, Anak Usia Dini

\footnotetext{
I UIN Sunan Kalijaga Yogjakarta, Email: email: 20204032017回student.uin-suka.ac.id

${ }^{2}$ UIN Sunan Kalijaga Yogjakarta, Email: email: Ichsanप|国uin-suka.ac.id
} 


\section{INTRODUCTION}

Giving stimulation to early childhood is very important for the further development of the children (Taznidaturrohmah et al., 2020). This is because early childhood is a sensitive period for children to receive stimulation or stimuli. One aspect of development that must be stimulated in early childhood is fine motor skills (Mahmud, 2019). Before the research, the researchers conducted interviews with educators in group B of TK Pertiwi 26-13 Bogares Kidul, researchers received information that teachers in group B of TK Pertiwi 26-13 Bogares Kidul had already done weaving activities and were used to it, and students could carry out according to the instructions of the educator and the output was quite good. for fine motor development. But the teachers only use paper for weaving. For this reason, researchers offer a solution for weaving materials by utilizing banana leaves that are environmentally friendly and easy to obtain without having to spend a lot of money.

$$
\text { Researchers also made }
$$

observations during the pre-survey that it was found that the activity of weaving is so vital for the development of children's fine motor skills. Finally, children felt that encouraged the teacher to discuss the problem. To strengthen the research background, the researchers reviewed previous research from Meriyati, Meriyati Kuswanto, Cahniyo Wijaya Pratiwi, Dona Dinda Apriyanti, Ela (Meriyati et al., 2020) in the PAUD journal. This research aims to capture the impact of weaving activities on the improvement of fine motor skills in early childhood. The results of the research show that weaving activities influence children's fine motor development Furthermore, research from Daulay, Winda Cahyani Nurmaniah (Daulay \& Nurmaniah, 2019) in early childhood journals which has aims to understand the impact of weaving activities on children's fine motor skills. Using quantitative approaches and methods. The results of the research show that there is a significant influence on weaving activities with children's fine motor skills. And Research from (Syamaun \& Irfani, 2019) in the journal of Child Education (JIPA). This research aims to improve fine motor skills by weaving using paper media. Using classroom action research approaches and methods. The results of the research show that children's fine motor skills can be developed by weaving using paper media.

In the research that has been carried out, the weaving activity in the research carried out by the researcher takes one of the natural ingredients so that the research is more specific, namely banana leaves as a weaving material. The reason researchers use banana leaves in weaving activities since it is easy to get it is environmentaly friendly. In the future, the woven products from children that are not comparable to those expected can be removed without polluting the surrounding environment.

\section{LITERATURE REVIEW}

The main basis for preparing children who have good quality is through education. Education is a conscious and planned effort to create conditions and the course of the learning process so that children are enthusiastic about exploring the abilities that exist in themselves (DEPDIKNAS, 2003).

Learning for early childhood based on the point of view of the origin of learning and development is a process that is interrelated between learning and development (Hartati, 2005). This means that learning experiences and early developments become the basis for the learning process and subsequent developments (Suyadi, 2014). Children who get good stimulation to elaborate the right brain and left brain get the full 
ability to be successful in entering the next level of education (Susanto, 2012).

The purpose of learning is to provide stimulation so that increase the child's ability to produce a brilliant generation. Not just providing a lot of mathematical knowledge, but preparing children mentally and physically to recognize the world around them in a friendly way (Sudjiono, 2012). With the right tutoring, all of their abilities will be developed.

In this study, the ability to be achieved is that children can use their motor skills well. Forming according to their imagination, children explore through activities and learning media, use writing utensils and eating utensils correctly, can squeeze and tear objects with their fingers, and can express themselves with movement(Depdiknas., 2014). The activity may seem easy but in fact, children need training and stimulation so they can develop their fine motor skills that are so vital for their growth and development (Fauziddin, 2018).

For that, we need to understand the meaning of fine motor first. The motor is an activity that implements certain body members, one of which is the ability to coordinate fingers and wrist activities correctly (Agustina et al., 2018). There are also those who define fine motor skills as the ability to use instruments with alignment between the eyes and hands(Fadlillah, 2012). For this reason, hand activities need to be stimulated properly so that initial skills such as forming straight lines, straight lines, and others can be developed.

The addition of basic motor skills is an activity that concretizes all children's abilities, both from actions, efforts and results that are given patterns, content and directional guidelines into a rounded personality based on the child's wishes(Hurlock, 1996). So the addition of motor skills can mean being part of the main education through activity knowledge, to the growth and development of children as a whole.

Developing children's fine motor skills can have an impact on children's readiness when writing, activities to train alignment between hands and eyes are recommended for a sufficient total period even though the use of intact hands cannot be fulfilled (Pamadhi dan Sukardi, 2010).

Fine motor capacity in children cannot grow on their own but must learn the skills that develop fine motor skills (Sujiono, 2010). For this reason, from an early age, children's fine motor development needs some activities that encouraging and providing stimulation for children's fine motor development. This activity is carried out with play activities. Children's motor activities can have good results in the perspective of other skill development (Saputra, 2005).

Weaving activities are a way to develop and have fine motor honing activities so that they can express creativity that can produce art works according to the child's imagination. In the activity of weaving, it requires a thorough, diligent, and skilled attitude, so it needs to be carried out patiently because it has artistic value (Pamadhi dan Sukardi, 2018)

For that, it can be defined that weaving is weaving woven craft materials so that they become objects that can meet daily needs, for example, bags, table mats, mats, and others (Rahmat dkk, 1994). Some interpret weaving as a skill activity that has the aim of creating various works of art, which are carried out employing penetrating each other or sticking woven pieces in alternate ways (Sumanto, 2005).

The activity of weaving has many benefits for children. One of the benefits is to stimulate fine motor development because weaving activities provide greater opportunities to harmonize hand and eye movements (Kusumaningtyas, 2018). 
One of the woven materials used in skill practice activities at TK Pertiwi 26-13 Bogares Kidul is banana leaves. The use of banana leaves in weaving application activities are the old one and have sufficient width. When using the banana leaf, it is torn according to the leaf fibers having a scale between one to two centimeters, then made woven according to the desired patterns. Not only are children capable of weaving these activities, but children can also introduce characters to the leaves.

Banana leaves are one of the natural ingredients that have many fuctions. One of the fuction of banana leaves is as a food wrapper. Banana leaves can be useful as woven crafts. Banana leaves can be used for weaving activities that can train fine muscles and can improve fine motor skills. Banana leaves are very environmentally friendly, easy to find, and can teach children that plants, namely banana leaves that are around us that were created by God, have many benefits and we can use them in various forms. If you want to create something, you don't have to bother looking for materials, banana leaves that are around us can be used and utilized.

\section{METHODOLOGY}

The research method carried out is quantitative research by conducting field research. The research method presents data in the form of points and the analysis of the data used has the characteristics of a count that has a direction to test hypotheses. There are twenty-five children as the population in group B TK Pertiwi 26-13 Bogares Kidul.

In this research, the researcher uses three research instruments for data collection, including observations during research, interviews to conduct interviews, and documentation to take physical evidence such as school profile documents or photos of research activities when children carry out banana leaf weaving activities.

In this research, the researcher uses a regression analysis model. The study of the relationship of one dependent variable (bound) to one or more independent variables (free). The aims are to estimate the population or dependent variable based on the value of the independent variable obtained (Sugiono, 2010). Before carrying out the research analysis, in order to get a good score, the researcher needs to carry out testing on the data collection instrument used by validity and reliability testing methods (Arikunto, 1993).

Reliability testing in this research using Cronbach Alpha's $(\alpha)$. With complete calculations and reliability testing, it is supported using the SPSS version 16.0 computer design for Windows (Ghozali, 2005).

Statistical data analysis is using a linear regression test (Hasan, 2004). In this research, simple regression analysis serves as a statistical technique used to test the impact of banana leaf weaving activities on fine motor skills in Pertiwi Kindergarten 26-13 Bogares Kidul children.

\section{RESEARCH RESULTS AND DISCUSSION}

Based on the results of observations carried out at TK Pertiwi 26-13 Bogares Kidul, it was shown that the variable of banana leaf weaving activity could contribute to increasing the fine motor skills of children in TK Pertiwi 26-13 Bogares Kidul. Next, the researcher wants to explain the results of the research that has been obtained from the observation sheet carried out at TK Pertiwi 26-13 Bogares Kidul containing responses from research variables. Assessment is carried out on each child based on components that already have response options classified as below: 
BB: Undeveloped

MB: Starting to Grow

BHS: Developing as Expected

BSB: Developing Very Well

The statement component becomes the response or behavior of the child to the things contained in the observation component based on what the children experience and feel that can influence the child's fine motor skills. This is evidenced by several statements on the observation sheet that weaving banana leaves can affect children's fine motor skills. Further described as below:

List 1 Fine Motor Development of Children in Group B1 Kindergarten Pertiwi 26-13 Bogares Kidul

\begin{tabular}{|c|c|c|c|c|c|c|c|}
\hline \multirow{2}{*}{$\begin{array}{l}\mathbf{N} \\
\mathbf{0}\end{array}$} & \multirow{2}{*}{$\begin{array}{c}\text { Name } \\
\text { of } \\
\text { Childre } \\
n\end{array}$} & \multicolumn{4}{|c|}{ Indikator } & \multirow{2}{*}{$\begin{array}{l}\text { T } \\
\text { ot } \\
\text { al }\end{array}$} & \multirow[b]{2}{*}{$\%$} \\
\hline & & 1 & $\begin{array}{c}\text { Scor } \\
\text { e }\end{array}$ & & & & \\
\hline 1 & ADIT & BB & 14 & 87,5 & BB & 14 & 87,5 \\
\hline 2 & INARA & BB & 13 & 81,2 & BB & 13 & 81,2 \\
\hline 3 & $\begin{array}{l}\text { AISYA } \\
\mathrm{H}\end{array}$ & $\mathrm{BB}$ & 13 & 81,2 & $\mathrm{BB}$ & 13 & 81,2 \\
\hline 4 & VINA & BB & 12 & 75 & BB & 12 & 75 \\
\hline 5 & HANA & BB & 11 & 68,7 & $\mathrm{MB}$ & 11 & 68,7 \\
\hline 6 & ZILA & BB & 12 & 75 & $\mathrm{MB}$ & 12 & 75 \\
\hline 7 & $\begin{array}{l}\text { FATTA } \\
\mathrm{H}\end{array}$ & BB & 8 & 50 & $\begin{array}{c}\mathrm{BS} \\
\mathrm{H}\end{array}$ & 8 & 50 \\
\hline 8 & BRIAN & $\mathrm{BB}$ & 12 & 75 & $\mathrm{MB}$ & 12 & 75 \\
\hline 9 & KEVIN & $\mathrm{BB}$ & 10 & 62,5 & MB & 10 & 62,5 \\
\hline 10 & QIYAH & BB & 8 & 50 & $\begin{array}{c}\mathrm{BS} \\
\mathrm{H}\end{array}$ & 8 & 50 \\
\hline 11 & LAILA & BB & 10 & 62,5 & MB & 10 & 62,5 \\
\hline 12 & EZA & BB & 10 & 62,5 & MB & 10 & 62,5 \\
\hline 13 & FARIZ & $\mathrm{BB}$ & 12 & 75 & $\mathrm{BB}$ & 12 & 75 \\
\hline 14 & ALLIF & BB & 11 & 68,7 & $\mathrm{MB}$ & 11 & 68,7 \\
\hline 15 & $\begin{array}{l}\text { MIFFT } \\
\text { AH }\end{array}$ & BB & 14 & 87,5 & BB & 14 & 87,5 \\
\hline 16 & NAJWA & $\mathrm{BB}$ & 12 & 75 & $\mathrm{BB}$ & 12 & 75 \\
\hline 17 & NAURA & BB & 9 & 56,2 & $\begin{array}{c}\mathrm{BS} \\
\mathrm{H}\end{array}$ & 9 & 56,2 \\
\hline 18 & PUTRA & BB & 13 & 81,2 & MB & 13 & 81,2 \\
\hline 19 & RAVVA & BB & 10 & 62,5 & BB & 10 & 62,5 \\
\hline 20 & $\begin{array}{l}\text { SEPTIA } \\
\text { NI }\end{array}$ & BB & 10 & 62,5 & MB & 10 & 62,5 \\
\hline
\end{tabular}

\begin{tabular}{llcccccc}
\hline 21 & $\begin{array}{l}\text { SHEIK } \\
\text { A }\end{array}$ & BB & 13 & 81,2 & BB & 13 & 81,2 \\
& & & & & & \\
\hline 22 & SUCI & BB & 12 & 75 & BB & 12 & 75 \\
\hline 23 & $\begin{array}{l}\text { SYAFI } \\
\text { Q }\end{array}$ & BB & 11 & 68,7 & MB & 11 & 68,7 \\
\hline 24 & TANIA & BB & 10 & 62,5 & MB & 10 & 62,5 \\
\hline 25 & $\begin{array}{l}\text { TRESY } \\
\text { A N }\end{array}$ & BB & 9 & 56,2 & BS & 9 & 56,2 \\
& & & & H & & \\
\hline
\end{tabular}

Indicators review

1: Tear the banana leaf well

2: Using fingers to weave well

3: Coordinate between eyes and hands while weaving

4: Able to follow the pattern of the chicken simple

List 2 Profit for Children's Fine Motor Development at TK Pertiwi 26-13 Bogares Kidul

\begin{tabular}{llll}
\hline No & Reviews & $\begin{array}{l}\text { Total } \\
\text { students }\end{array}$ & Profit \\
\hline 1 & BSB & 0 & $0 \%$ \\
\hline 2 & BSH & 2 & $8 \%$ \\
\hline 3 & MB & 18 & $72 \%$ \\
\hline 4 & BB & 5 & $20 \%$ \\
\hline & Total & 25 & $100 \%$ \\
\hline
\end{tabular}

We can see that the profit indicator Increases Equal Desires (IED) is at the point of seventy-two percent, which used to be sixty-four percent, which means that almost all banana leaf weaving activities outperform children's fine motor skills development. Next, the researcher conducted a hypothesis test in order to obtain provisional results from research activities, and the regression coefficient verification was intended to test the relevance of the impact of the independent variable.

(A) is, the activity of weaving banana leaves on the dependent variable (B), namely fine motor skills. For this reason, it can be found that the independent variable affects the dependent variable in the research. In the following segment, the results of research that have been obtained with observations carried out at TK Pertiwi 
26-13 Bogares Kidul will be presented in the form of responses to research variables, namely banana leaf weaving activities and children's fine motor skills. The following is the response of the
Variable Banana Leaf Weaving. The response cycle based on the banana leaf weaving variable can be seen as below:

List 3 Analysis of Observation Results Assessment of Banana Leaf Weaving

\begin{tabular}{cccccccccccc}
\hline \multirow{2}{*}{ No } & Pernyataan & \multicolumn{10}{c}{ Tanggapan } \\
\cline { 3 - 12 } & & \multicolumn{1}{c}{ MDP 1 } & \multicolumn{1}{c}{ MSK 2 } & \multicolumn{1}{c}{ SM 3 } & \multicolumn{2}{c}{ TM 4 } & \multicolumn{2}{c}{ TOTAL } \\
\cline { 2 - 13 } & & $\mathrm{R}$ & $\%$ & $\mathrm{R}$ & $\%$ & $\mathrm{R}$ & $\%$ & $\mathrm{R}$ & $\%$ & $\mathrm{R}$ & $\%$ \\
\hline 1 & $\mathrm{~A} 1$ & 10 & 40 & 2 & 8 & 13 & 52 & 0 & 0 & 25 & 100 \\
\hline 2 & $\mathrm{~A} 2$ & 1 & 4 & 13 & 52 & 10 & 40 & 1 & 4 & 25 & 100 \\
\hline 3 & $\mathrm{~A} 3$ & 12 & 8 & 8 & 32 & 13 & 52 & 2 & 8 & 25 & 100 \\
\hline 4 & A4 & 15 & 60 & 4 & 26 & 6 & 64 & 0 & 0 & 25 & 100 \\
\hline
\end{tabular}

Based on the table, it shows that half of the respondents are improving well and increasing as desired, but some start to increase and do not increase. From the response to the first statement, A1 is tearing forty percent of banana leaves. In statement A2 is the activity of tearing banana leaves according to the fiber of the leaves, most of the respondents increased as desired with the acquisition of fifty-two percent. In a statement, A3 Banana leaf weaving mostly starts growing with a gain of fiftytwo percent. From statement, A4 Weaving banana leaves follows a simple pattern with eye-hand coordination by sixty-four percent.

Researchers also analyzed fine motor assessment observations such as:

List 4 Analysis of Assessment Observation Results

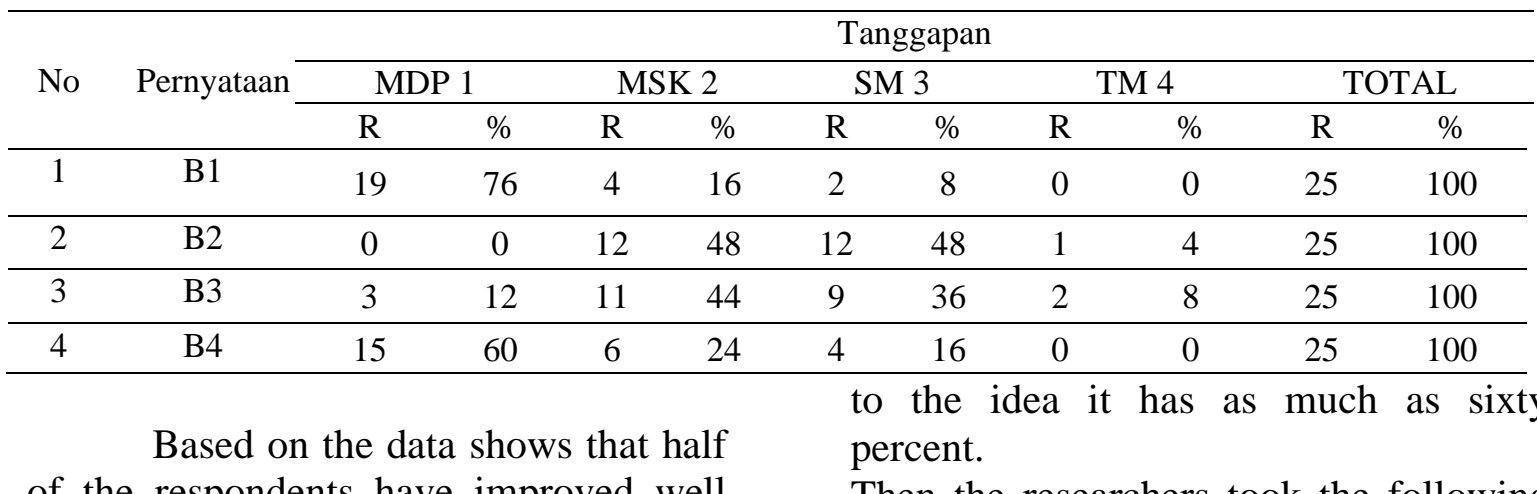

of the respondents have improved well and have increased according to desire, but there is some start to increase and not increase. From the response to the first statement, B1 is tearing a banana leaf with his fingers as much as seventy-six percent. From statement B2, that is to weave a simple banana leaf with handeye coordination, which is forty-eight percent. Statement B3 is to weave a simple pattern of banana leaves as much as forty-four percent. From the statement, B4 is to weave with a pattern according
Then the researchers took the following steps:

\section{A. Validity Test}

To test the validity of this research, the SPSS version 16.0 for Windows method was used. In point research, it is recognized as valid if the Corrected Item Total Correlation point is obtained more than or equal to 0.396. Point 0.396 is calculated through the Point Distribution Table $r$ table with an increase of $5 \%$.

1. Test the validity of the variable Banana leaf weaving activity 
List 5 Variable Validity Test Results for banana

\begin{tabular}{llcrl}
\hline No & $\begin{array}{c}\text { Item } \\
\text { Statement }\end{array}$ & $\begin{array}{c}\text { Correlation } \\
\text { Coefficient }\end{array}$ & $\begin{array}{r}\text { rtabel } \\
\mathrm{n}=25 ; \\
\mathrm{df}=5 \%\end{array}$ & Key \\
\hline 1 & Q1 & 0.403 & 0.396 & Valid \\
\hline 2 & Q2 & 0.461 & 0.396 & Valid \\
\hline 3 & Q3 & 0.702 & 0.396 & Valid \\
\hline 4 & Q4 & 0.380 & 0.396 & Valid \\
\hline
\end{tabular}

Based on the material on processing the product variable validity test material, the results obtained rcount $>$ rtable, as well as an increase point (0.000) with points less than 0.05. For this reason, each part of the statement in the questionnaire from variable $\mathrm{A} 1$ is recognized as valid.

\section{B. Test the Validity of Fine Motor Activity Variables}

List 6 Fine Motor Activity Variable

Validity Test Results

\begin{tabular}{lllll}
\hline No & $\begin{array}{l}\text { Item } \\
\text { Statement }\end{array}$ & $\begin{array}{l}\text { Correlation } \\
\text { Coefficient }\end{array}$ & $\begin{array}{l}\text { rtabel } \\
\mathrm{n}=25 ; \\
\mathrm{df}=5 \%\end{array}$ & Key \\
\hline 1 & Q1 & 0.403 & 0.396 & Valid \\
\hline 2 & Q2 & 0.461 & 0.396 & Valid \\
\hline 3 & Q3 & 0.702 & 0.396 & Valid \\
\hline 4 & Q4 & 0.380 & 0.396 & Valid \\
\hline
\end{tabular}

Based on the data on the results of the preparation of the product variable validity test data, the results obtained count $>\mathrm{r}$ table, and the increase point (0.000) with points less than 0.05. For this reason, each part of the statement in the questionnaire so that the B2 variable is recognized as valid.

Validity Test Instruments declared valid must be able to estimate what you want to estimate on the variables being researched. A validity test using Pearson's bivariate through the power of $95 \%$ confidence $(\alpha=0.05)$ was carried out by correlating the value of each unit on the point number. Furthermore, the correlation point ( $r$ count) that has been obtained is compared to the correlation point in the table ( $r$ table). If the point $r$ count is greater than the $r$ table, it means that there is a correlation point that shows that the measuring instrument is valid, and vice versa. The $r$ table point for an increase of $5 \%$ or 0.05 with a total sample or $n=25$ is 0.207 .

\section{Reliability Test}

In this research, the reliability test is out using Cronbach Alpha's $(\alpha)$. All assessments and credibility tests were assisted using SPSS. When tested for reliability using a point limit of 0.60 . If the point obtained by the reliability is less than 0.60 then the result is declared bad.

The draft Credibility assessment specifications are grouped according to the levels as below:

As long as point alpha $(\alpha)$ is several:

0.8-10: Good credibility

0.6-0.799: Credibility accepted

Less than 0.6: Credibility is not good

The results of the credibility testing carried out on the research instrument are presented in table six as follows:

List 7 Credibility test results

\begin{tabular}{llll}
\hline No & Variable & $\begin{array}{c}\text { Alpha } \\
\text { Cronbach's }\end{array}$ & Description \\
\hline 1 & $\begin{array}{l}\text { Banana } \\
\text { leaf } \\
\text { weaving } \\
\text { activity }\end{array}$ & 0.200 & Credible \\
\hline 2 & $\begin{array}{l}\text { Fine } \\
\text { Motor } \\
\text { Activity }\end{array}$ & 0.305 & Credible \\
\hline
\end{tabular}

Based on the test, the estimation of the coefficient of the Cronbach Alpha of the four variables is > 0.6. For this reason, it can be concluded that all parts of the good statement on the independent variable or the dependent variable are Credible.

\section{Simple Linear Regression Analysis}

Research using simple regression analysis acts for statistical techniques used to test whether or not there is an 
effect of banana leaf weaving activity on fine motor skills in Pertiwi Kindergarten 26-13 Bogares Kidul children.

The simple linear regression formula is:

\section{$\mathrm{A}=\mathrm{c}+\mathrm{dB}$}

Information:

$\mathrm{A}=$ Fine motor skills

$\mathrm{c}=$ constant

$\mathrm{X}=$ Weaving banana leaves

$\mathrm{b}=$ Regression coefficient of banana leaf weaving

Through simple linear regression, it can be found that there is an effect of banana leaf weaving activity on fine motor activities.

List 7 Regression Analysis Results Coefficientsa

\begin{tabular}{|c|c|c|c|c|c|}
\hline \multirow[t]{2}{*}{ Model } & \multicolumn{2}{|c|}{$\begin{array}{l}\text { Unstandardize } \\
\text { d Coefficients }\end{array}$} & $\begin{array}{c}\text { Stand } \\
\text { ardize } \\
d \\
\text { Coeffi } \\
\text { cients }\end{array}$ & \multirow[t]{2}{*}{$\mathrm{T}$} & \multirow{2}{*}{$\begin{array}{l}\text { Signi } \\
\text { fikan. }\end{array}$} \\
\hline & B & $\begin{array}{l}\text { Stan } \\
\text { dar. } \\
\text { Kesa } \\
\text { lahan }\end{array}$ & Beta & & \\
\hline (Constant) & 5.592 & 2.152 & & $\begin{array}{r}2.59 \\
8\end{array}$ & .016 \\
\hline $\begin{array}{c}\text { MENGAYA } \\
\text { M DAUN } \\
\text { PISANG }\end{array}$ & .579 & .190 & .536 & $\begin{array}{r}3.04 \\
2\end{array}$ & .006 \\
\hline
\end{tabular}

a. Dependent Variable: WEAKING BANANA LEAVES

The regression equation obtained in the estimation results is as follows:

$\mathrm{B}=(\mathrm{c}+\mathrm{BA})$

$\mathrm{B}=5.592+0.579 \mathrm{~A}$

What is meant is:

$\mathrm{B}=$ Fine Motor Activity Variable

$\mathrm{A}=$ Banana leaf weaving activity variable From the regression equation it can be concluded:

The constant 5.592 is said if the independent variable point is 0 , then the element determination is influenced by fine motor activity as much as 5.592
The regression coefficient A (banana leaf weaving activity variable) of 0.579 explains the activity variable

Weaving banana leaves has a good impact on motor activity

fine. This is due to

Banana leaf weaving activity can train motor skills in children.

Verification of the regression coefficients aims to test the increase in the impact of the independent variable, namely the activity of weaving banana leaves, with, independent (t-test) on the dependent variable, namely fine motor activity. For this reason, it can be found whether the independent variables affect the dependent variable in the research.

\section{E. Linearity test}

The linearity test has the aim of getting the interaction between variable $A$ and variable $B$ linear or not. In linearity estimation, it is used to get data estimation. Independent variables interact linearly or not with dependent variables.

The decision standard uses the point comparison rule Sig. (2-tailed) from the ANOVA table with an increased rate of $0.05(5 \%)$ If on the ANOVA coefficient $>0.05$, for that the interaction on the independent variable is linear, the opposite if on the ANOVA coefficient < 0.05 , for that the interaction of variables on the dependent variable is not linear. The linearity test was carried out using an analysis of variance with a $G$ value.

Based on the reaction of data compilation so that linearity testing uses statistical applications assisted by SPSS version 16.0. for windows, is through the method of sorting the list: Analyze Compare Means - Means and clicked Test of Linearity, the test reaction is obtained as below: 
List 8 Linearity Test (A) with (B)

ANOVA Table

\begin{tabular}{|c|c|c|c|c|c|}
\hline \multirow[t]{2}{*}{ Model } & \multicolumn{2}{|c|}{$\begin{array}{l}\text { Unstandardiz } \\
\text { ed } \\
\text { Coefficients }\end{array}$} & \multirow{2}{*}{$\begin{array}{c}\text { Standar } \\
\text { dized } \\
\text { Coeffic } \\
\text { ients } \\
\text { Beta }\end{array}$} & \multirow[t]{2}{*}{$\mathrm{T}$} & \multirow[t]{2}{*}{ Sig. } \\
\hline & B & $\begin{array}{c}\text { Std. } \\
\text { Error }\end{array}$ & & & \\
\hline (Constant) & $\begin{array}{r}5.59 \\
2\end{array}$ & 2.152 & & 2.598 & .016 \\
\hline $\begin{array}{c}\text { MOTORI } \\
\text { K HALUS }\end{array}$ & .579 & .190 & .536 & 3.042 & .006 \\
\hline
\end{tabular}

Based on the ANOVA data, it can be found that the point $G$ in the Deviation of Linearity section is 1,193 and the point Sig. (2-tailed) is 0.291. Then the point Sig.(2-tailed) is more than the addition point of $0.05(5 \%)$, For this reason, it can be concluded that the interaction between the independent variable and the dependent variable has a linear nature.

F. $\mathrm{t}$-test

The t-test is a test in order to obtain the influence independently between the independent variables on the dependent variable. In order to carry out the $\mathrm{t}$-test, the proposed hypothesis is as follows:

H1: Banana leaf weaving affects children's fine motor skills.

Weaving banana leaves has an influence on fine motor activity. If tcount is greater than ttable, then $\mathrm{H} 0$ is rejected and $\mathrm{H} 1$ is accepted, meaning that there is an influence on the independent variable on the dependent variable. This is the preparation of the preparation of data that can be obtained at the research site.

The formula for getting the $\mathrm{t}$ table is: $(\alpha / 2 ; n-k-1)$ Where: = belief arrangement $\mathrm{k}=$ Total response $\mathrm{k}=$ Total Independent Variables if $\mathrm{t}$ table $=0.05 / 1 ; 25-1-1=$ $0.05 ; 23$ ttable $=$ number $0.05 ; 23$ then obtained the transfer of ttable points obtained as many as 1,714. $t$ table points

List 8 t test Coefficientsa

\begin{tabular}{|c|c|c|c|c|c|c|c|}
\hline & & & $\begin{array}{l}\text { Sum of } \\
\text { Squares }\end{array}$ & $\mathrm{df}$ & $\begin{array}{l}\text { Mean } \\
\text { Square }\end{array}$ & G & Sig \\
\hline \multirow{4}{*}{$\begin{array}{l}\text { Motorik Halus } \\
\text { Between } \\
\text { Mengayam } \\
\text { daun pisang }\end{array}$} & Groups & $\begin{array}{c}\text { (Combine } \\
\text { d) }\end{array}$ & 5246.158 & 42 & 124.909 & 1.166 & .315 \\
\hline & & Linearity & 7.613 & 1 & 7.613 & .071 & .791 \\
\hline & & Deviation & & & & & \\
\hline & & $\begin{array}{c}\text { from } \\
\text { Linearity }\end{array}$ & 5238.545 & 41 & 127.769 & 1.193 & .291 \\
\hline Within Groups & & & 4176.867 & 39 & 107.099 & & \\
\hline Total & & & 9423.024 & 81 & & & \\
\hline
\end{tabular}

a. Dependent Variable: FINE MOTOR In the results of the assessment, it is obtained that the count points are $2,598>1,717$ with an increasing point of $0.02>0.05$. For this reason, it can be concluded that $\mathrm{H} 0$ is rejected and $\mathrm{H} 1$ is accepted which means that the banana leaf weaving activity variable has an increasing effect on the fine motor activity variable.

The first hypothesis is that the variable of banana leaf weaving activity has an influence on fine motor activity, it is acceptable. It can be obtained at the point count of the banana leaf weaving activity variable as much as 2,598> 1,717 through an increasing point of 0.02> 
0.05 . The independent variable of banana leaf weaving activity affected both and increased the dependent variable of fine motor activity. For this reason, it can be stated that if students do not practice through banana leaf weaving activities, the children's fine motor skills cannot increase.

Based on the data analysis described above, shows that an increase in children's creativity can be increased through banana leaf weaving activities. This can be seen from the children being able to use their motor skills well, besides that the children have good eye-hand coordination when weaving banana leaves.

\section{CONCLUSION}

Based on the reaction analysis and analysis that has been carried out in this research, conclusions can be drawn: The multiple linear regression equation for the research is as follows: $\mathrm{B}=5.592+$ 0.579A Variable Banana leaf weaving has a good and increasing effect on fine motor skills. It is shown at 0.000 points. For this reason, the hypothesis (H1) is that banana leaf weaving activity has a good and increasing effect on the development of Fine Motor Ability, it is acceptable.

\section{REFERENCES}

Agustina, S., Nasirun, M., \& D, D. (2018). Meningkatkan Keterampilan Motorik Halus Anak Melalui Bermain dengan Barang Bekas. Jurnal Ilmiah Potensia, 3(1), 24-33. https://ejournal.unib.ac.id/index.php/ potensia/article/view/2963

Arikunto. (1993). Prosedur Penelitian Suatu Pendekatan Praktek. Jakarta: Rineke Cipta.

Daulay, W. C., \& Nurmaniah. (2019). Pengaruh Kegiatan Menganyam Terhadap Keterampilan Motorik Halus Pada Anak Usia 5-6 Tahun Di Tk Al-Ihsan Medan T . A 2018 / 2019. Jurnal Usia Dini, 5(2), 7-19.
Depdiknas. (2014). Pedoman Pembelajaran Bidang Pengembangan Motorik di Taman Kanak-Kanak. Jakarta: Depdiknas. DEPDIKNAS. (2003). Undang-Undang No.20 Tahun 2003 tentang Sistem Pendidikan Nasional. https://kelembagaan.ristekdikti.go.id /wpcontent/uploads/2016/08/UU_no _20_th_2003.pdf pada 22 Juli 2019

Fadlillah. (2012). Desain Pembelajaran PAUD. Jogjakarta: Ar-Ruzz Media.

Fauziddin, M. (2018). Meningkatkan Kemampuan Motorik Halus melalui Teknik Mozaik pada Anak Kelompok B di TK Perdana Bangkinang Kota. Journal of Studies in Early Childhood Education (J-SECE), 1(1), 1. https://doi.org/10.31331/sece.v1i1.5 81

Ghozali, I. (2005). Aplikasi Analisi Multi Variate dengan Program SPSS. Semarang :Badan Penerbit UNDIP.

Hartati, S. (2005). Perkembangan Belajar Pada Anak Usia Dini. Jakarta: Depdiknas Dirjen Pendidikan Tinggi.

Hasan, I. (2004). Analisis Penelitian Data Dengan Stastistik. Jakarta :Bumi Aksara.

Hurlock. (1996). Perkembangan Motorik Anak Usia Dini, . Jakarta: PT Rineka Cipta.

Kusumaningtyas, L. E. (2018). Meningkatkan Motorik Halus Melalui Kolase Dari Ampas Kelapa Pada Anak Tk Kelas B Usia 5-6 Tahun. Jurnal Audi, 2(2), 76-82. https://doi.org/10.33061/ad.v2i2.197 2

Mahmud, B. (2019). Urgensi Stimulasi Kemampuan Motorik Kasar Pada Anak Usia Dini. DIDAKTIKA: Jurnal Kependidikan, 12(1), 76-87. https://doi.org/10.30863/didaktika.v $12 \mathrm{i} 1.177$

Meriyati, M., Kuswanto, C. W., Pratiwi, D. D., \& Apriyanti, E. (2020). Kegiatan Menganyam dengan 
Bahan Alam untuk Mengembangkan Kemampuan Motorik Halus Anak. Jurnal Obsesi: Jurnal Pendidikan Anak Usia Dini, 5(1), 729. https://doi.org/10.31004/obsesi.v5i1. 667

Pamadhi, H. \& Sukardi, E (2010). Seni Keterampilan Anak, (Jakarta: Universitas Terbuka, 2010).

Rahmat dkk. (1994). Kapita Selekta. Jakarta: Departemen Pendidikan dan Kebudayaan.

Saputra, Y. M. (2005). Pembelajaran Kooperatif Untuk Meningkatkan Keterampilan Anak TK. Jakarta: Depdiknas.

Sudjiono, Y. N. (2012). Konsep dasar Pendidikan anak Usia Dini. Jakarta: Indeks.

Sugiono. (2010). Metode Penelitian Kuantitaif Kualitatif $R \& D$. Bandung: Alfabeta.

Sujiono, B. dkk. (2010). Metode Pengembangan Fisik. Jakarta: Universitas Terbuka.

Sumanto. (2005). Pengembangan Kreativitas Seni Rupa Anak TK. Jakarta: Departemen Pendidikan Nasional Direktorat Jenderal Pendidikan Tinggi.

Susanto, A. (2012). Perkembangan anak usia dini. Jakarta: Kencana Perdana Media Group.

Suyadi. (2014). Teori Pembelajaran Anak Usia Dini dalam Kajian Neurosains. Bandung, Remaja Rosdakarya.

Syamaun, A., \& Irfani, N. (2019). Meningkatkan Kemampuan Motorik Halus Anak Kelompok a Melalui Kegiatan Melipat. Jurnal Ilmiah Pendidikan Anak (JIPA). http://jurnal.stkipannur.ac.id/index.php/jipa/article/view $/ 116$

Taznidaturrohmah, Y. E., Pramono, P., \& Suryadi, S. (2020). Upaya meningkatkan kemampuan motorik halus melalui kegiatan montase pada anak kelompok B di TK Dharma
Wanita Dinoyo 01 Mojokerto. Jurnal Pendidikan Anak, 9(1), 2026.

https://doi.org/10.21831/jpa.v9i1.29 805 